\title{
Partisipasi Anggota Gapoktan pada Program Pengembangan Usaha Pangan Masyarakat (PUPM) melalui Toko Tani Indonesia (TTI) di Kabupaten Tulung Agung
}

\section{Participation of Gapoktan Members in the Community Food Business Development Program (PUPM) through the Indonesian Farmer Shop (TTI) in Tulung Agung Regency}

\author{
Oleh : \\ Sri Subekti ${ }^{1 *}$ dan Nadya Nur Sariningrum ${ }^{2}$ \\ ${ }^{1}$ Program Studi Penyuluhan Pertanian, Fakultas Pertanian, Universitas Jember \\ ${ }^{2}$ Program Studi Agribisnis, Fakultas Pertanian, Universitas Jember \\ Jl. Kalimantan No.37, Sumbersari, Jember, 68121, Jawa Timur, Indonesia \\ *Email : bekti.faperta@unej.ac.id
}

Received: February 02, 2021; Revised: May 21, 2021; Accepted June 7, 2021

\begin{abstract}
ABSTRAK
Pembangunan pertanian menuju ketahanan pangan diwujudkan pemerintah melalui program PUPMTTI. Program PUPM-TTI bertujuan memotong rantai pasok yang panjang sehingga memberikan harga layak untuk petani dan harga pangan terjangkau untuk konsumen. Tujuan dari penulisan untuk mengkaji partisipasi anggota Gapoktan pada program PUPM-TTI di Kabupaten Tulungagung. Pemilihan lokasi penelitian dengan Purposive Method. Penelitian kualitatif dengan penentuan informan Purposive Sampling. Pengumpulan data dengan metode wawancara, observasi dan dokumentasi. Analisis data yang digunakan yaitu analisis data Miles and Huberman. Hasil penelitian menunjukkan bahwa partisipasi anggota gapoktan Harapan Makmur dalam pengambilan keputusan dengan melakukan pembagian tugas dan mengikuti pelatihan, membagi saluran komunikasi, menentukan kebutuhan baru, menyepakati prosedur pertemuan, menyepakati kriteria pemimpin, kerjasama dengan pihak lain. Partisipasi dalam pelaksanaan dengan bersedia memberikan sumberdaya, administrasi dan koordinasi dan Enlishment. Pemanfaatan hasil meliputi keuntungan material, sosial dan personal. Evaluasi dilakukan secara internal dan eksternal.
\end{abstract}

Kata Kunci : Gapoktan, Ketahanan Pangan, PUPM-TTI, Partisipasi

\begin{abstract}
Agricultural development towards food security are implemented by the government through PUPMTTI program. Aims of PUPM-TTI program are to simplify supply chains to provide best prices for farmers and affordable prices for consumers. The purpose of this writ are to examine the participation of Gapoktan members in the Pengembangan Usaha Pangan Masyarakat (PUPM) through the Toko Tani Indonesia (TTI) in Tulungagung Regency. Research location are select with Purposive Method. Qualitative research with purposive sampling on informant selection. Collecting data using interviews, observation and documentation. Data analysis by Miles and Huberman. The results showed that the participation of members of the Harapan Makmur Gapoktan made decisions by distributing tasks and participating in training, sharing communication channels, determining new needs, agreeing on meeting procedures, agreeing on criteria for leaders, collaborating with other parties. Participation in implementation by willing to provide resources, administration and coordination and Enlishment. Benefit are includes material, social and personal benefits. Evaluation are held internally and externally.
\end{abstract}

Keywords : Gapoktan, Food Security, PUPM-TTI, Participation 


\section{PENDAHULUAN}

Pembangunan pertanian dapat diwujudkan dengan memenuhi syarat pelancar pembangunan yaitu pendidikan sistem pertanian, kredit produksi, kelembagaan petani, rehabilitasi lahan dan perencanaan pembangunan pertanian. Pendidikan sistem pertanian kepada petani menjadi salah satu solusi untuk mengubah pola pikir petani dari pertanian subsisten menjadi bisnis sehingga peningkatan pengetahuan petani dan memacu pertumbuhan produktivitas bahan pangan pokok. Pendidikan untuk petani dapat melalui program untuk meningkatkan kesejahteraan petani maupun konsumen, salah satunya melalui Program Pengembangan Usaha Pangan Masyarakat (PUPM) melalui Toko Tani Indonesia (TTI) (Mosher, 1967 dalam Arifin, 2005).

Konsep utama Program PUPM-TTI adalah menjamin harga pembelian dengan mempertimbangkan keuntungan petani melalui penerapan harga beli gabah yang wajar dan harga eceran yang terjangkau di masyarakat. Tujuan Program PUPM-TTI dapat mewujudkan ketahanan pangan dengan melindungi produsen dari jatuhnya harga jual dan melindungi konsumen dari tingginya harga beli sehingga tercipta tata niaga pangan yang berkeadilan. Program PUPM-TTI dilaksanakan secara berjenjang dan terpadu melibatkan instansi di tingkat pusat dan daerah, Pendamping, Gapoktan/Lembaga Usaha Pangan Masyarakat (LUPM) beserta Toko Tani Indonesia. Pelaksanaan kegiatan PUPM tingkat pusat dilaksanakan oleh Tim Pokja Pusat. Pelaksanaan kegiatan PUPM tingkat daerah adalah Tim Pembina Provinsi dan Tim Teknis Kabupaten/Kota serta Gapoktan selaku pengelola pemanfaatan dana bantuan pemerintah harus membentuk Unit Pelaksana Kegiatan PUPM-TTI (Badan Ketahanan Pangan, 2016).

Penelitian Kalesaran et al, 2015, mengenai partisipasi pada program top-down menyatakan bahwa partisipasi dapat dinilai dari komponen pengambilan keputusan, pelaksanaan, evaluasi, dan pemanfaatan hasil. Partisipan berperan aktif terutama pada tahun-tahun pertama masuknya program untuk mengikuti setiap pertemuan atau rembuk.

Program PUPM-TTI telah mulai dilaksanakan sejak tahun 2016 di 32 provinsi. Kabupaten Tulungagung merupakan salah satu kabupaten yang memiliki Gapoktan pelaksana program PUPM-TTI terbanyak di Provinsi Jawa Timur yakni lima Gapoktan dengan melibatkan 10 TTI. Program PUPMTTI di Kabupaten Tulungagung telah dilaksanakan sejak tahun 2016 di lima Gapoktan di kecamatan yang berbeda, yaitu Kecamatan Tulungagung, Sumbergempol, Gondang, Bandung dan Sendang dengan 5(lima) Gapoktan Pelaksana yaitu Gapoktan Harapan Makmur, Gapoktan Mardi Rukun, Gapoktan Ngudi Makmur, Gapoktan Dewi Sri dan Gapoktan Kop.Jasa Tirta.

Perkembangan PUPM-TTI di Tulungagung yang telah berjalan selama 4 tahun mengalami kendala yaitu penurunan antusiasme anggota gapoktan yang kurang konsisten dalam menjalankan Program PUPM-TTI disertai berbagai kendala yang dihadapi seperti hasil panen yang tidak menentu dan bergantung pada penggilingan swasta sehingga memunculkan ketimpangan antara progres Gapoktan Harapan Makmur dengan empat Gapoktan lain penerima program PUPM-TTI Tahun 2016. Gapoktan Harapan Makmur yang mampu menghimpun gabah dari anggota-anggotanya, telah memiliki penggilingan mandiri dan sistem penggudangan yang baik untuk menunjang program, berproduksi secara rutin dan mampu memasok produk secara kontinyu ke TTI. Keberlanjutan pelaksanaan suatu program dalam gapoktan tak lepas dari partisipasi anggota gapoktan sesuai dengan petunjuk teknis program PUPM TTI bahwa Gapoktan selaku pengelola pemanfaatan dana pemerintah harus membentuk Unit Pelaksana Kegiatan PUPM dari petani anggota selaku produsen dan pedagang selaku distributor pada wilayah masingmasing (Badan Ketahanan Pangan, 2016).

Eksistensi Gapoktan Harapan Makmur dalam melaksanakan Program PUPM-TTI 
menjadikan keinginan peneliti untuk menggali tentang partisipasi anggota gapoktan di Kabupaten Tulungagung dalam menjalankan Program PUPM-TTI. Tujuan penulisan adalah untuk mengkaji partisipasi anggota Gapoktan pada program Pengembangan Usaha Pangan Masyarakat (PUPM) melalui Toko Tani Indonesia (TTI) di Kabupaten Tulungagung.

\section{METODE PENELITIAN}

Lokasi pelaksanaan penelitian di Desa Wates Kecamatan Sumbergempol Kabupaten Tulungagung dengan pertimbangan: (1) Kabupaten Tulungagung memiliki potensi terbesar pada komoditas padi (2)Wilayah yang dipetakan oleh Badan Ketahanan Pangan Kementrian Pertanian sebagai penerima program PUPM-TTI terbanyak di Jawa Timur dengan 5 gapoktan penerima di Tahun 2016. Metode yang digunakan dalam penelitian ini adalah metode kualitatif dengan pendekatan evaluatif untuk melihat pencapaian suatu program atau pendekatan untuk melihat pelaksanaan teori dibanding dengan keadaan di lapang Patton (1990) dalam Elizabeth (2007). Metode penentuan informan yang digunakan yaitu purposive sampling yang merupakan teknik penentuan informan secara sengaja dengan pertimbangan : (1) Mengetahui tentang kondisi pertanian di Kabupaten Tulungagung terutama di Desa Wates pada lahan untuk aspek produksi Program PUPM-TTI. (2) Mengetahui alur operasional program PUPM-TTI (3)Terlibat langsung dalam perencanaan hingga evaluasi program PUPM-TTI. (4) tonggak utama pada Gapoktan Angkatan pertama yaitu tahun 2016 yang secara aktif dan berkelanjutan melaksanakan program PUPM-TTI di Kabupaten Tulungagung (5)Jujur, terbuka dan cakap dalam berbicara.Informan yang memenuhi kriteria tersebut adalah Ketua Gapoktan, anggota gapoktan yang terdiri dari petani, pedagang, dan wanita tani serta tim teknis dan pendamping(Etikan, 2016).

Pengumpulan data dilakukan dengan wawancara, observasi dan dokumentasi.
Dokumentasi data sekunder yang digunakan adalah: (1)dokumen dari Gapoktan, (2) dokumen dari Dinas Ketahanan Pangan Kabupaten Tulungagung, dan (3) dokumen dari Badan Pusat Statistik Kabupaten Tulungagung. Model analisis yang digunakan adalah Miles dan Huberman dengan tahapan meliputi pengumpulan data, reduksi data, penyajian data dan penarikan kesimpulan. Miles dan Huberman menyatakan bahwa aktivitas analisis data kualitatif dilakukan secara interaktif dan berlangsung secara berkelanjutan(Sugiyono, 2006)

\section{HASIL DAN PEMBAHASAN}

\section{Gambaran Umum Desa Wates}

Desa Wates merupakan desa yang terletak di bagian selatan wilayah Kecamatan Sumbergempol yang berbatasan dengan wilayah kecamatan Kalidawir dengan luas wilayah $215,7 \mathrm{Ha}$. Jarak dengan ibu kota kecamatan $7 \mathrm{~km}$, jarak dengan kota kabupaten Tulungagung $14 \mathrm{~km}$. Desa Wates terbagi atas dua dusun dengan $3 \mathrm{RW}$ dan 10 RT yaitu Dusun Duwet dan Dusun Nglegok. Desa Wates terletak di hilir Sungai Brantas dan dilalui oleh DAS Brantas secara langsung sehingga mendukung untuk budidaya tanaman pangan seperti padi serta palawija.

\section{Partisipasi Anggota Gapoktan pada Program PUPM-TTI}

Partisipasi adalah gerakan anggota masyarakat atau anggota lembaga untuk terlibat dalam proses pengambilan keputusan, pelaksanaan kegiatan, memperoleh manfaat dari kegiatan serta terlibat dalam evaluasi kegiatan(Sumardjo dan Saharudin, 2003 dalam Fahrudin, 2012). Gabungan Kelompok Tani atau Gapoktan berperan untuk mempermudah penyaluran bantuan pemerintah dan menampung kebutuhan yang dibutuhkan petani sehingga penyaluran bantuan lebih efisien dan merata. Gabungan Kelompok Tani atau Gapoktan 
diharapkan mampu menjadi tonggak dalam mengatasi permasalahan yang dialami oleh petani selaku produsen yaitu harga pangan yang berfluktuasi(Ratna, 2012)

Pelaksanaan kajian Partisipasi Anggota Gapoktan Pada Program Pengembangan Usaha Pangan Masyarakat (PUPM) melalui Toko Tani Indonesia (TTI) Di Kabupaten Tulungagung diidentifikasi dengan empat jenis partisipasi menurut Cohen \& Uphoff (1980) yaitu decision making(pengambilan keputusan), implementation (pelaksanaan), benefit (pemanfaatan hasil) dan evaluation (evaluasi).

\section{Decision making (pengambilan} keputusan)

Menurut Cohen \& Uphoff (1980) partisipasi dalam pengambilan keputusan berpusat pada pembentukan gagasan dan pemahaman, perumusan tentang yang perlu dilakukan untuk mempersiapkan program, dan membuat opsi tentang cara mengaplikasikan modal sesuai ketentuan, termasuk perumusan rencana untuk menerapkan opsi yang dipilih. Berdasarkan pertimbangan tersebut maka terdapat tiga jenis keputusan yang dapat dikaji (a) initial decision (keputusan awal), (b) on going decision (keputusan saat berlangsungnya program), dan (c) operational decision (keputusan operasional).

\section{a. Initial Decision (keputusan awal)}

Partisipasi dalam pengambilan keputusan awal meliputi pemahaman program, pembagian tugas, dan persiapan untuk menerima program. Anggota gapoktan dapat memahami dan menjelaskan kembali dengan bahasa sendiri berdasarkan dari pemahaman pribadi yang merupakan modal utama untuk berpartisipasi. Program PUPMTTI merupakan program yang memberikan modal kepada Gapoktan penerima untuk menjalankan usaha yaitu menyerap gabah petani anggota gapoktan, memproses gabah menjadi beras, menjual kepada warga di wilayah Gapoktan. Ungkapan singkat bahwa beras dari petani Desa Wates, diolah oleh Gapoktan Wilayah Wates dan dikonsumsi oleh warga Wates selaras dengan tujuan program PUPM-TTI yang memangkas rantai distribusi pangan yang terlalu panjang sehingga petani memperoleh harga gabah yang layak dan konsumen mendapat harga yang terjangkau.

Gapoktan Harapan Makmur telah membentuk tiga divisi dalam menjalankan program PUPM-TTI yaitu divisi produksi (tanam hingga panen), pengolahan (gabah hingga beras), dan penjualan (TTI ke konsumen). Divisi Produksi bertugas dan saling berkoordinasi dalam hal produksi meliputi pembenihan, penanaman, pemupukan dan pengairan, panen hingga pasca panen pengeringan gabah. Divisi Pengolahan bertugas dan saling berkoordinasi dalam hal pengolahan meliputi penggilingan, pengemasan dan pengiriman menuju TTI. Divisi Penjualan bertugas bertugas dan saling berkoordinasi dalam hal pemasaran produk, pembukuan penjualan dan promosi. Penanggungjawab masingmasing divisi bertugas untuk mengawal hasil kesepakatan harus disesuaikan dengan penerapannya di lapang.

Persiapan program dilakukan dengan usaha penguatan organisasi untuk memberikan fondasi yang kuat dalam pelaksanaan program. Penguatan organisasi dilakukan melalui forum pelatihan untuk memberikan pendidikan secara non formal kepada petani dengan harapan dapat meningkatkan pengetahuan serta motivasi dalam berorganisasi.

b. On Going Decision (keputusan saat berlangsungnya program)

Partisipasi anggota gapoktan dalam pengambilan keputusan saat berlangsungnya program meliputi partisipasi dalam menentukan alur komunikasi, merumuskan kebutuhan baru dan menentukan prioritas kegiatan. Alur komunikasi tentang program PUPM-TTI dibagi menjadi empat saluran untuk mempermudah transfer informasi yaitu pertemuan dinas dengan seluruh anggota, pertemuan dinas dengan pengurus, pertemuan antar pengurus, dan pertemuan internal seluruh anggota. Pertemuan Dinas 
Ketahanan Pangan dengan seluruh anggota berlangsung ketika program diluncurkan, materi yang dibahas adalah pengertian program, hak kewajiban dalam program, dan teknis pelaksanaan. Pertemuan Dinas Ketahanan Pangan dengan pengurus diadakan 3 bulan sekali dengan materi yang dibahas adalah terkait pelaksanaan dan pertanggungjawaban penggunaan dana modal program PUPM-TTI. Pertemuan antar pengurus dilaksanakan secara insidental menyesuaikan dengan kebutuhan, pertemuan antar pengurus dilakukan ketika terjadi situasi yang mendesak dan membutuhkan keputusan yang cepat. Pertemuan dengan seluruh anggota gapoktan dilaksanakan setiap awal tanam untuk menyepakati varietas yang digunakan, pupuk yang digunakan dan pengelolaan air. Pertemuan dengan seluruh anggota gapoktan juga dilaksanakan tiap tahun untuk mengevaluasi hasil kerja dalam 1 tahun.

Anggota Gapoktan Harapan Makmur menganalisa adanya kebutuhan baru yaitu perlu diadakan diversifikasi produk. Anggota Gapoktan berpendapat menambahkan opsi bahan pangan pokok selain beras seperti gula, minyak goreng atau telur untuk menambah jenis bahan yang dijual dan dapat lebih menarik konsumen, namun saat ini seluruh gapoktan penerima program PUPMTTI di Kabupaten Tulungagung masih berfokus pada produksi beras.

Prioritas kegiatan Gapoktan Harapan Makmur disesuaikan dengan musim panen dan musim paceklik yang mempengaruhi harga beras. Prioritas kegiatan Gapoktan Harapan Makmur pada saat musim panen adalah penimbunan yang dilakukan oleh tim pengumpul gabah dengan mencari informasi lahan siapa yang sedang panen kemudian melakukan pembelian dengan harga sedikit diatas harga pasar. Gabah yang akan dibeli harus minimal berasal dari varietas padi medium dan kadar air rendah. Gabah yang dibeli kemudian disimpan di Gudang Penyimpanan milik Gapoktan Harapan Makmur atau biasa disebut dengan Lumbung. Gabah akan diselep saat harga beras baik dan dikemas untuk kemudian diedarkan ke TTI.
Anggota gapoktan dapat mengolah atau menggiling gabah hasil produksi atau menyimpannya sehingga dapat meningkatkan nilai tambah produk petani (Akbar, 2013)

\section{c. Operational Decision (keputusan operasional)}

Partisipasi anggota gapoktan dalam pengambilan keputusan operasional meliputi partisipasi dalam membagi komposisi anggota, merumuskan kebutuhan baru dan menentukan prioritas kegiatan, menentukan teknis pertemuan dan menentukan kriteria pemimpin. Anggota Gapoktan Harapan Makmur telah membagi komposisi anggota sesuai dengan petunjuk teknis Program PUPM-TTI. Profesi yang dilibatkan adalah petani selaku produsen gabah dan pedagang selaku pengelola TTI untuk menyalurkan beras ke konsumen. Pelaksanaan Program PUPM-TTI di Gapoktan Harapan Makmur dilengkapi dengan partisipasi wanita tani 'Sekar Makmur' yang merupakan bagian dari Gapoktan Harapan Makmur. Partisipasi wanita tani Sekar Makmur adalah membantu rekapitulasi pembukuan TTI sebelum dilaporkan ke bendahara dan membantu persiapan 'ubarampe' untuk acara dalam tradisi Gapoktan salah satunya adalah panen raya.

Komunikasi formal dalam organisasi terjadi berdasarkan tingkatan struktur dalam organisasi sehingga orang yang memiliki posisi tinggi lebih dihormati dan diperlakukan secara formal. Rapat komunikasi formal di Gapoktan Harapan Makmur diselenggarakan dalam bentuk pertemuan resmi dengan surat undangan tertulis setiap 1 tahun dan 3 bulan sekali yang dihadiri oleh pengurus, pendamping, dan seluruh anggota gapoktan. Komunikasi informal di Gapoktan Harapan Makmur berupa arisan setiap 2 minggu sekali yang bertujuan untuk mempererat silahturahmi dan koordinasi antara pengurus, petani, pedagang, peternak dan wanita tani. Anggota gapoktan menyepakati terdapat syarat dimulainya setiap pertemuan yaitu harus memenuhi $50 \%$ peserta, apabila belum 
memenuhi jumlah minimal peserta maka pertemuan akan ditunda hingga jumlah peserta memenuhi.

Penentuan kriteria pemimpin dengan sikap low profile cenderung lebih terbuka dalam pergaulannya, bersedia menerima kritik orang lain sehingga kehadirannya lebih diterima dan disegani oleh anggotanya. Kriteria pemimpin yang dinyatakan oleh anggota gapoktan Harapan Makmur dimana seorang pemimpin sebaiknya disegani oleh anggota, jujur dan dapat mengorganisasikan anggota dengan baik sehingga menciptakan suasana kerja yang nyaman sesuai dengan kriteria pemimpin yang baik dengan sikap low profile. Ketua Gapoktan Harapan makmur merupakan salah satu figur yang dipilih anggota sesuai dengan kriteria tersebut. Ketua Gapoktan menjadi rujukan dalam pemecahan masalah lapang maupun urusan keorganisasian.

Pelaksanaan program PUPM-TTI memerlukan kerjasama dengan organisasi lain, baik organisasi formal maupun informal. Lembaga formal yang memberikan dukungan terhadap pelaksanaan PUPM-TTI di Gapoktan Harapan Makmur adalah Pemerintah Desa Wates dan Dinas Ketahanan Pangan. Pemerintah Desa Wates memberikan fasilitas berupa tanah untuk perluasan lumbung serta perbaikan saluran air yang menjadi fasilitas dasar untuk memperlancar tahap produksi dan penyimpanan. Dinas Ketahanan Pangan memberikan fasilitas alat mesin pertanian terutama RMU (Rice Milling Unit) sehingga gapoktan Harapan Makmur dapat mengolah gabah secara mandiri. Lembaga Informal yang memberikan dukungan terhadap pelaksanaan PUPM-TTI di Gapoktan Harapan Makmur adalah Kios pupuk resmi "Tani Makmur" yang berada di Dusun Duwet Desa Wates Kecamatan Sumbergempol. Kios pupuk memberikan fasilitas dengan bersedia menjadi penjual perantara pupuk bersubsidi. Penebusan pupuk bersubsidi dari agen harus kontan yang memberatkan gapoktan sehingga bekerjasama dengan kios pupuk agar anggota gapoktan bisa menebus pupuk sesuai kebutuhan dan diperbolehkan untuk melunasi pembayaran dengan tenggang waktuhingga masa panen tiba. Lembaga formal adalah memiliki struktur yang jelas dan aturan tertulis serta sasaran yang terencana dengan jelas, sedangkan lembaga informal adalah lembaga yang terbentuk dalam masyarakat (Hakimi, 2019)

\section{Implementation (pelaksanaan)}

Menurut Cohen \& Uphoff (1980)partisipasi anggota gapoktan dalam pelaksanaan partisipasi dalam kegiatan operasional berdasar program yang telah ditetapkan dan bentuk yang dipartisipasikan dapat melalui tiga cara yang dapat dikaji yaitu (a) kontribusi sumber daya (Resource Contribution); (b) administrasi dan koordinasi (Administration and coordination); dan (c) Enlishment.

\section{a. Kontribusi sumber daya (Resource Contribution)}

Kontribusi sumberdaya yang diberikan anggota gapoktan Harapan Makmur meliputi kontribusi tenaga kerja, dana, bahan konsumsi dan informasi. Kontribusi tenaga kerja tercermin dari sikap gotong royong masih lekat dengan sikap warga desa seperti halnya sikap anggota gapoktan Harapan Makmur untuk mencapai tujuan bersama yaitu menekan biaya tenaga kerja. Anggota gapoktan bersedia membantu tenaga dan meluangkan waktu secara sukarela dalam penggilingan gabah dan pengemasan demi menekan biaya produksi. Langkah tersebut ketika harga beras berfluktuasi dan cenderung turun sehingga keuntungan yang diperoleh semakin tipis.

Kontribusi dana dari anggota inti sebanyak 30 orang masing-masing memberikan dana sebesar Rp. 500.000,untuk membangun lumbung yang lebih luas dan lebih bersih. Lumbung dilengkapi dengan fasilitas penggudangan yang baik dengan menggunakan palet kayu sebagai alas danlantai jemur. Tanah untuk membangun lumbung dibantu oleh Pemerintah Desa yang merupakan tanah bengkok (tanah milik lurah) untuk kepentingan bersama. 
Kontribusi anggota akan barang konsumsi dipengaruhi oleh tradisi warga desa yang akan merasa rikuh atau segan jika tidak memberi kontribusi, walaupun suatu acara telah dicukupi oleh dana yang terkumpul di Gapoktan, sehingga timbul keinginan anggota untuk memberikan kontribusi walaupun hal kecil yang terjangkau tetapi dibutuhkan misalkan dengan menyumbangkan pisang, air mineral, suguhan, dan saat panen raya membawa ambeng sebagai wujud rasa syukur kepada Tuhan dan saling berbagi rezeki kepada sesama. Ciri utama budaya agraris tradisional pada sistem ekonomi pertanian adalah penekanan pada nilai kebudayaan dan adat. Masyarakat melihat nilai-nilai yang penting dalam kehidupan sosial yang menekankan pada penghindaran konflik dan kompetisi, rukun dan rikuh (Darmanto, 1995).

Anggota gapoktan juga ikut menyediakan informasi kepada sesama petani yang diperoleh dari pendidikan dan pelatihan. Transfer informasi melalui praktek langsung oleh rekan satu profesi lebih efektif daripada hanya melalui teori karena hasilnya akan langsung terlihat. Perubahan yang dirasakan oleh petani anggota gapoktan adalah penggunaan pupuk berimbang.

b. Administrasi dan koordinasi

\section{(Administration and coordination)}

Partisipasi anggota Gapoktan Harapan Makmur dalam administrasi dan koordinasi meliputi pembentukan kelompok lokal, komunikasi masalah, promosi dan pembukuan. Pembentukan kelompok tani pada awalnya dilakukan melalui pendekatan domisili, namun kemudian dimodifikasi mengikuti hamparan lahan pertanian untuk mempermudah koordinasi dan pengairan. Satu petak mulai tanam maka petak lain akan mengikuti sehingga fase tanam lebih serempak. Ketua HIPPA dipilih petani yang memang memiliki lahan di hamparan tersebut sehingga tidak hanya sekedar mengaliri saja, namun juga ikut mengelola dan memahami langsung permasalahan yang terjadi di lahan. Partisipasi yang efektif adalah dengan meningkatkan kemampuan kerja sama dalam ikatan kelompok tani hamparan sebagai media interaksi untuk perubahan perilaku melalui adopsi tata nilai, teknologi, dan struktur yang relevan, dan kemampuan kerja sama dalam kelompok menjadi dasar keberhasilan kelompok dalam melaksanakan teknologi (Zakaria \& Rachman, 2013)

Komunikasi masalah dilakukan anggota gapoktan dengan 2 cara yaitu secara personal dan kelompok. Komunikasi masalah secara personal dengan cara mendatangi langsung pengurus atau pendamping sehingga dapat lebih leluasa saling sharing dan mendapatkan solusi permasalahan dengan cepat. Komunikasi masalah secara personal sering digunakan untuk mengatasi permasalahan yang memerlukan penanganan yang cepat. Komunikasi masalah dalam kelompok melalui pertemuan rutin sebelum masa tanam dengan pokok pembahasan tentang solusi untuk serangan hama dan penggunaan pupuk berimbang. Tujuan komunikasi masalah kelompok adalah untuk mengatasi permasalahan yang terjadi secara luas dan agar dapat melaksanakan penanggulangan secara komprehensif. Komunikasi personal yang paling berperan adalah sesama petani dalam lingkungannya. Petani yang berprestasi merupakan andalan yang menjadi rujukan, karena melalui petani teladan petani lain dapat langsung mencontoh cara usahatani yang baik dan mengkomunikasikan masalah (Pertiwi \& Saleh, 2010)

Anggota gapoktan Harapan Makmur secara mandiri melakukan promosi yang dikemas dalam acara karnaval kebudayaan, dengan menghadirkan kesenian daerah jaranan untuk menarik perhatian. Karnaval Budaya Desa Wates dikenal meriah sehingga banyak orang yang datang dari desa lain bahkan kecamatan lain hanya untuk menyaksikan karnaval tersebut. Karnaval budaya menjadi kesempatan yang sangat baik untuk memperkenalkan produk Program PUPM-TTI dengan nama dagang "Beras Segar" dalam ukuran $5 \mathrm{~kg}$. Anggota 
Gapoktan membuka stand dengan dilengkapi banner yang berada digaris Start sekaligus garis Finish yang berada di Balai Desa Wates sehingga mudah terlihat oleh pengunjung karnaval.

Pembukuan dalam program PUPMTTI diwajibkan untuk Gapoktan dan TTI. Aspek yang dicatat gapoktan adalah asal pengadaan gabah, jumlah pembelian gabah, jumlah hasil pengolahan gabah, jumlah yang dipasok ke TTI. Aspek yang dicatat oleh TTI adalah pengadaan dari gapoktan, nama pembeli, alamat pembeli, jumlah pembelian, dan mengadakan rekapitulasi setiap minggu dan bulan. Evaluasi pembukuan Gapoktan dan pembukuan TTI akan dengan diperiksa dan dicocokan setiap produk terjual sebanyak kelipatan satu kuintal sehingga dapat dicocokkan jumlah hasil penjualan dengan stok yang masih tersedia. Pedoman teknis menyebutkan salah satu kewajiban gapoktan melakukan pencatatan dan menyusun pembukuan keuangan dan barang ke dalam buku kas kegiatan PUPM serta buku pembelian dan penjualan sesuai dengan kuitansi/nota/faktur pembelian/penjualan. Pedoman teknis menyebutkan salah satu kewajiban TTI adalah melakukan pencatatan dan pembukuan terkait pengadaan, penjualan dan stok beras dari Gapoktan/LUPM (Badan Ketahanan Pangan, 2016).

\section{c. Enlishment}

Berdasarkan penelitian Cohen dan Uphoff (1980), partisipasi dalam Enlishment berkaitan dengan kesediaan anggota gapoktan untuk melibatkan diri dan menerima konsekuensi setelah progam dilaksanakan. Anggota gapoktan menyepakati dua ketentuan hasil kesepakatan bersama yaitu dalam pemilihan varietas dan penentuan kadar air minimum.

Pemilihan varietas padi didasarkan pada keadaan lahan produksi, potensi hama dan karakteristik beras yang dihasilkan. Anggota gapoktan sepakat untuk lebih memilih varietas padi Inpari 42 karena berkualitas medium sesuai dengan standar dalam petunjuk teknis program PUPM-TTI, produktivitas lebih tinggi, tahan terhadap

hama wereng coklat yang banyak terjadi di Desa Wates, dan tahan terhadap kekeringan dimana posisi Desa Wates yang berada di hilir sungai sehingga air irigasi yang diperoleh tidak menentu.

Kadar air mempunyai pengaruh penting dalam standar beras karena menentukan kondisi kritis dimana mikroorganisme dapat tumbuh dan merusak kualitas beras. Petani anggota gapoktan telah terbiasa untuk mengeringkan gabahnya dengan baik walau tidak dapat mengukur secara riil kadar air gabah yang telah dikeringkan, namun untuk gabah yang akan disuplai ke gapoktan telah dikeringkan lebih kering dari biasanya. Gapoktan juga melakukan kontrol terhadap mutu beras yang akan diterima yaitu harus dalam keadaan kering karena beras yang basah beresiko patah, warna beras yang tidak bersih dan berat giling tidak maksimal.

\section{Benefit (pemanfaatan hasil)}

Menurut Cohen \& Uphoff (1980) partisipasi dalam pemanfaatan hasil dapat menjadi salah satu jenis partisipasi yang lebih pasif, namun pemanfaatan hasil selalu lekat dengan setiap kegiatan ekonomi. Partisipasi dalam pemanfaatan hasil dapat dikaji melalui tiga aspek yaitu (a) material benefit (manfaat material) (b) social benefit (manfaat sosial) (c) personal benefit (manfaat personal).

\section{a. Material Benefit (manfaat material)}

Rekapitulasi keuangan Gapoktan
Harapan Makmur menunjukkan bahwa
gapoktan mendapatkan laba sebesar Rp.
3.600.000,- selama program berjalan.
Keuntungan yang diperoleh dari program
PUPM TTI ini sangat minim sehingga
mustahil untuk dibagikan satu per satu
kepada anggota sehingga keuntungan
tersebut diwujudkan menjadi kegiatan yang
dapat dinikmati seluruh anggota.
Keuntungan dari program PUPM-TTI
kemudian dihimpun oleh gapoktan dan
digunakan untuk membiayai kegiatan
bersama seperti panen raya dan studi
banding.


Anggota gapoktan memperoleh manfaat material dengan diberi fasilitas alat mesin yang diberikan oleh gapoktan, justru sering ditawari oleh pihak gapoktan untuk menggunakannya apabila lahan kekurangan air. Aset alat mesin pertanian yang dimiliki gapoktan adalah RMU (Rice Milling Unit), pengolah kompos (chopper), mesin tanam (Rice Transplanter), mesin pemamanen (Combine Harvester), Handtractor, dan pompa air. Anggota yang meminjam alat mesin pertanian dari Gapoktan tidak dipungut biaya sewa dan sudah disediakan operatornya, cukup menyediakan bahan bakar untuk operasionalnya.

\section{b. Social Benefit (manfaat sosial)}

Program PUPM-TTI ini memberikan semangat baru kepada gapoktan untuk mempererat koordinasi dan menambah semangat untuk menuju orientasi bisnis. Manfaat adanya program PUPM-TTI ini juga dapat dirasakan masyarakat khususnya warga Desa Wates sehingga mampu memperbaiki hubungan gapoktan dengan masyarakat bahwa TTI yang disuplai oleh Gapoktan Harapan Makmur menjadi penyedia bahan pangan berkualitas dengan harga yang terjangkau. Tujuan dari program PUPM TTI adalah menjadikan gapoktan sebagai Lembaga Usaha Pangan Masyarakat (LUPM ) yang merupakan lembaga usaha bersama yang berkembang di masyarakat bergerak di bidang produksi/usaha pangan, berorientasi bisnis, memiliki struktur organisasi dan berkekuatan hukum serta memberikan kemudahan akses konsumen/masyarakat terhadap bahan pangan pokok dan strategis, dengan harga yang terjangkau dan wajar (Badan Ketahanan Pangan, 2016)

\section{c. Personal Benefit (manfaat personal)}

Program PUPM-TTI memberikan pengalaman kepada anggota gapoktan bahwa terjun di dalam dunia bisnis beras merupakan hal yang tidak mudah dan memacu tumbuh jiwa bisnis dari tingkat petani. Anggota gapoktan terutama petani memperoleh pengalaman bahwa untung dan rugi merupakan hal yang pasti akan dialami oleh pengusaha, sehingga menjadikan fokus yang penting untuk mencari solusi agar tetap eksis dalam menjalankan program PUPMTTI. Solusi yang dilakukan adalah dengan promosi salah satunya saat karnaval budaya. Program PUPM-TTI merupakan sarana untuk membina anggota gapoktan menjadi lebih mandiri, dengan ikut terjun dalam program PUPM-TTI anggota gapoktan menjadi lebih kritis dalam berwirausaha dan mampu berorientasi bisnis (Badan Ketahanan Pangan, 2016)

\section{d. Evaluation (evaluasi)}

Menurut Cohen \& Uphoff (1980), partisipasi dalam dalam kegiatan evaluatif yang bertujuan untuk menghimpun masukan dari pelaksana dan memastikan program berjalan sesuai dengan tujuan yang ingin dicapai, dengan harapan penerima program memiliki kesadaran akan konsekuensi dan dapat menilai kelanjutan atau kemungkinan perbaikan pelaksanaan suatu program. Partisipasi dalam evaluasi meliputi upaya dan keterlibatan lokal dalam evaluasi program (internal) serta keterlibatan pihak berwenang (eksternal). Menurut Sanders and Sullins (1976) dalam Mardikanto (1993),Evaluasi internal merupakan evaluasi yang diadakan secara internal oleh anggota yang bekerja langsung pada program. Evaluasi ekstern adalah evaluasi yang dilaksanakan oleh pihak luar, evaluasi dapat muncul dari kalangan orang luar, atau dilaksanakan oleh organisasi pemilik atau pelaksana program yang bersangkutan.

\section{Evaluasi Internal}

Evaluasi internal Gapoktan Harapan Makmur dilakukan setiap satu tahun sekali bersamaan dengan kegiatan RAT (Rapat Anggota Tahunan) dimana seluruh anggota gapoktan diundang untuk mengikuti evaluasi dan masing masing diberikan copy rekapitulasi keuangan sehingga berjalan secara transparan, dalam evaluasi internal dilaporkan aset keseluruhan, aset per 
program, aliran kas masuk dan kas keluar. Tujuan diadakannya evaluasi internal adalah untuk membahas program yang telah berjalan, melakukan sosialisasi laporan pertanggungjawaban dan membahas rencana kerja untuk satu tahun ke depan. Evaluasi internal dilakukan secara terbuka dan transparan bagi anggota gapoktan namun bersifat khusus hanya untuk anggota dan pengurus gapoktan sehingga tidak melibatkan pihak lain seperti pihak desa agar keputusan mufakat yang diambil tidak mendapat intervensi dari pihak luar.

\section{Evaluasi Eksternal}

Evaluasi eksternal dilaksanakan oleh Dinas Ketahanan Pangan dan perwakilan anggota gapoktan. Evaluasi eksternal dilakukan dengan pertemuan resmi dan kunjungan lapang. Aspek yang menjadi titik berat dalam evaluasi adalah penggunaan dana anggaran yang diperiksa dari saldo yang ada di rekening dan pembukuan. Kunjungan lapang untuk melihat secara langsung perkembangan Gapoktan Harapan Makmur dengan memeriksa asset berupa stok gabah,stok beras, gudang dan alat mesin. Kegiatan monitoring dan evaluasi yang terjadwal dari pihak stakeholder dan perlu adanya perhatian lebih dalam proses evaluasi sehingga partisipasi anggota yang terlibat selaku partisipan dapat ditingkatkan (Embaranas, 2016)

\section{SIMPULAN}

Partisipasi anggota gapoktan Harapan Makmur melakukan pengambilan keputusan dengan melakukan pembagian tugas dan mengikuti pelatihan, membagi saluran komunikasi, menentukan kebutuhan baru, menyepakati prosedur pertemuan, menyepakati kriteria pemimpin, kerjasama dengan pihak lain. Partisipasi dalam pelaksanaan dengan bersedia memberikan sumberdaya tenaga kerja, dana, bahan konsumsi, informasi, membentuk kelompok lokal, menentukan saluran komunikasi masalah, menentukan cara promosi, melakukan pembukuan, menentukan kriteria kadar air gabah, dan pemilihan varietas padi. Pemanfaatan hasil meliputi keuntungan material yang dihimpun gapoktan, perubahan pola piker petani menuju orientasi bisnis, pangan murah berkualitas bagi masyarakat, pengalaman tentang bisnis beras,dan menumbuhkan semangat bisnis di tingkat petani. Evaluasi dilakukan secara internal yaitu antar anggota dan eksternal yaitu anggota, pengurus dan tim teknis.

\section{DAFTAR PUSTAKA}

Akbar, M.Rizza. 2013. Pengaruh Budaya Organisasi terhadap Employee Engagement (Studi pada Karyawan PT..Primatexco Indonesia di Batang). Social and Industrial Psychology, 2(1) : 10-18.

Arifin, B. (2005). Pembangunan Pertanian: Paradigma Kebijakan dan. Strategi Revitalisasi. Jakarta: PT. Grasindo.

Badan Ketahanan pangan. (2016). Pedoman Teknis Pengembangan Usaha Pangan Masyarakat Tahun 2016. Jakarta: Kementrian Pertanian.

Badan Ketahanan pangan. 2016. Pedoman Umum Pengembangan Usaha Pangan Masyarakat Tahun 2016. Jakarta: Kementrian Pertanian

Cohen M. John and N.T. Uphoff. (1980). Participation's Place in Rural Development: Seeking Clarity through Specificity. World Development, 8(1), 213-235.

Darmanto. 1995. Solah tingkah orang-orang Indonesia: esai-esai tentang transformasi budaya. Semarang : Badan Penerbit Universitas Diponegoro

Elizabeth, Roosganda. 2007. Fenomena Sosiologis Metamorphosis Petani: ke Arah Keberpihakan pada Masyarakat Petani di Pedesaan yang Terpinggirkan terkait Konsep Ekonomi Kerakyatan. Forum Penelitian Agro Ekonomi. Volume 25 No. 1, Juli 2007 : $29-42$.

Embaranas, Pramestiti. 2016. Partisipasi Masyarakat Dalam Program Kelompok 
Usaha Bersama (Kube) di Kota Malang. Universitas Negeri Surabaya: 1-16.

Etikan, Ilker, S.A.Musa, R.S.Alkassim. 2016. Comparison of Convenience Sampling and Purposive Sampling. American Journal of Theoretical and Applied Statistics, 5(1): 1-4.

Fahrudin, Adi (2012). Pemberdayaan Partisipasi dan Penguatan Kapasitas Masyarakat. Bandung : Humaniora.

Hakimi Rini, M.Noer, Nofialdi, Hasnah. 2019. Peran Lembaga Formal dan Informal Dalam Pengembangan Agroindustri Di Kabupaten Limapuluh Kota. Ekonomi Pertanian dan Agribisnis (JEPA). 3 (3) : 511-525.

Kalesaran, Ferdinand, V.V. Rantung, N.R. Pioh. 2015. Partisipasi dalam Program Nasional Pemberdayaan Masyarakat Mandiri Perkotaan Kelurahan Taas Kota Manado. Acta Diurna, 9 (5) :1-13.
Mardikanto, T. (1993). Penyuluhan Pembangunan Pertanian. Surakarta : UNS. Press.

Pertiwi, P. R. dan A. Saleh. 2010. Persepsi Petani tentang Saluran Komunikasi Usahatani. Padi Komunikasi Pembangunan, 08 (2) : 1-16.

Ratna, D.Puspita, Wuradji, dan N.Djazifah. 2012..Pemberdayaan Petani melalui Gabungan Kelompok Tani (Gapoktan). Diklus, 16 (02) : 140-148.

Sugiyono. (2006). Metode Penelitian Kuantitatif Kualitatif dan R\&D. Bandung: Alfabeta.

Zakaria K, Amar dan B. Rachman. 2013. Implementasi Sosialisasi Intensif Ekonomi dalam Pelaksanaan Program Perlindungan Lahan Pertanian Pangan Berkelanjutan (PLP2B). Pusat Ekonomi dan Kebijakan Pertanian, (1): 137-149. 